\title{
Detection of vertical root fractures in the presence of artefacts by digital radiography and cone beam computed tomography
}

\author{
Detecção de fraturas radiculares verticais na presença de artefatos por radiografia digital e
} tomografia computadorizada de feixe cônico

Detección de fracturas radiculares verticales en presencia de artefactos por radiografía digital y tomografía computarizada de haz cónico

Rosany Laurentina Santos de Carvalho ORCID: https://orcid.org/0000-0001-7602-4568 Universidade de Pernambuco, Brazil E-mail: rosanycarvalho@ hotmail.com

Flavia de Lima Cavalcanti Spinelli ORCID: https://orcid.org/0000-0002-6180-0402 Universidade de Pernambuco, Brazil E-mail: flavinha.delima@ hotmail.com

Luciana Sarmento de Mendonça ORCID: https://orcid.org/0000-0001-9468-878X Universidade de Pernambuco, Brazil

E-mail: lucianasarmento@yahoo.com.br

José Alcides Almeida de Arruda

ORCID: https://orcid.org/0000-0002-6599-3950

Universidade Federal de Minas Gerais, Brazil E-mail: alcides_almeida@hotmail.com

Amália Moreno

ORCID: https://orcid.org/0000-0002-3474-2091

Universidade Federal de Minas Gerais, Brazil E-mail: amalia_moreno@yahoo.com.br

Pamella Recco Alvares

ORCID: https://orcid.org/0000-0003-3396-9339 Universidade de Pernambuco, Brazil E-mail: pamellarecco@ hotmail.com

Cleomar Donizeth Rodrigues

ORCID: https://orcid.org/0000-0003-2222-6388 Faculdades Integradas da União Educacional do Planalto Central, Brazil E-mail: cleomar.d.rodrigues@gmail.com

Ana Paula Veras Sobral

ORCID: https://orcid.org/0000-0002-0801-9385 Universidade de Pernambuco, Brazil E-mail: anapvsobral@yahoo.com.br

Marcia Maria Fonseca da Silveira ORCID: https://orcid.org/0000-0002-2611-5661 Universidade de Pernambuco, Brazil E-mail: marcia.m.f.s@hotmail.com

\begin{abstract}
The correct diagnosis of vertical root fractures (VRF) in the presence of artifacts is a challenge for clinicians and endodontists. Moreover, there is controversy about which imaging technique is best for this purpose. In an in vitro model, we evaluated the diagnosis of VRF in teeth treated endodontically with and without intraradicular metal posts, using the Clark technique and cone beam computed tomography (CBCT), as well as the interference of artifacts with the diagnosis. Twenty-two first or second maxillary or mandibular premolars were included. Teeth were randomly allocated to three groups: G1 (two teeth without fracture with endodontic treatment and one with an intraradicular metal post); G2 (10 fractured teeth with endodontic treatment); and G3 (10 fractured teeth with endodontic treatment plus a metal post). The examiners recorded the presence or absence of fracture and its location and classified its type. There was no statistically significant difference between image acquisition systems. When differentiating the teeth (first $v s$. second premolars), there was a statistically significant difference among the examiners $(p=0.020)$. However, when comparing the values obtained by the examiners regarding the visualization of the fracture site as well as the presence of fracture correlated with the presence of a metal post and angulation, there were no statistically significant differences
\end{abstract}


( $p>0.05$ ). Digital radiographs and CBCT were similar for the diagnosis of VRF. High sensitivity was observed by CBCT image reconstructions. Therefore, the presence of metal posts generated artifacts, resulting in low sensitivity, specificity and accuracy.

Keywords: Cone beam computed tomography; Radiography dental digital; Diagnosis.

\section{Resumo}

O diagnóstico correto de fraturas radiculares verticais (FRV) na presença de artefatos é um desafio para clínicos e endodontistas. Além disso, há controvérsias sobre qual técnica de imagem é a melhor para esse fim. Em modelo in vitro, avaliamos o diagnóstico de FRV em dentes tratados endodonticamente com e sem pinos metálicos intrarradiculares, pela técnica de Clark e tomografia computadorizada de feixe cônico (TCFC), bem como a interferência dos artefatos no diagnóstico. Vinte e dois primeiros ou segundos pré-molares superiores ou inferiores foram incluídos. Os dentes foram alocados aleatoriamente em três grupos: G1 (dois dentes sem fratura com tratamento endodôntico e um com pino intrarradicular metálico); G2 (10 dentes fraturados com tratamento endodôntico); e G3 (10 dentes fraturados com tratamento endodôntico mais um pino metálico). Os examinadores registraram a presença ou ausência de fratura e sua localização e classificaram o tipo. Não houve diferença estatisticamente significativa entre os sistemas de aquisição de imagens. Na diferenciação dos dentes (primeiros vs. segundos pré-molares), houve diferença estatisticamente significativa entre os examinadores $(\mathrm{p}=0,020)$. Porém, ao comparar os valores obtidos pelos examinadores quanto à visualização do local da fratura, bem como a presença de fratura correlacionada com a presença de pino metálico e angulação, não houve diferenças estatisticamente significantes ( $p>0,05)$. As radiografias digitais e a TCFC foram semelhantes para o diagnóstico de FRV. Alta sensibilidade foi observada por reconstruções de imagem TCFC. Portanto, a presença de pinos metálicos gerou artefatos, resultando em baixa sensibilidade, especificidade e precisão.

Palavras-chave: Tomografia computadorizada de feixe cônico; Radiografia dentária digital; Diagnóstico.

\section{Resumen}

El correcto diagnóstico de fracturas radiculares verticales (FRV) con presencia de artefactos es un desafio para endodoncistas y dentistas generales. Además de ello, existe controversia sobre qué técnica de imagen es mejor para este propósito. El objetivo del presente trabajo fue evaluar el diagnóstico de FRV en dientes tratados endodónticamente con y sin postes metálicos intrarradiculares, utilizando la técnica de Clark y tomografía computarizada de haz cónico (TCHC), así como la interferencia de artefactos en el diagnóstico, in vitro. Se utilizaron veintidós primeros o segundos premolares maxilares o mandibulares. Los dientes fueron distribuidos aleatoriamente en tres grupos: G1 (dos dientes sin fractura con tratamiento endodóntico y uno con poste intrarradicular metálico); G2 (10 dientes fracturados con tratamiento endodóntico); y G3 (10 dientes fracturados con tratamiento endodóntico más un poste metálico). Los examinadores registraron la presencia o ausencia de fractura, el tipo y su ubicación. Los resultados mostraron que no hubo diferencia estadísticamente significativa entre los sistemas de adquisición de imágenes. En relación al tipo de diente utilizado (primeros y segundos premolares), hubo una diferencia estadísticamente significativa entre los examinadores $(\mathrm{p}=0,020)$. Sin embargo, al comparar los valores obtenidos por los examinadores con respecto a la visualización del sitio de la fractura, así como la presencia de fractura correlacionada con la presencia de poste metálico y angulación, no hubo diferencias estadísticamente significativas ( $>>0,05)$. Las radiografías digitales y TCHC fueron similares para el diagnóstico de FRV. Se observó una alta sensibilidad mediante reconstrucciones de imágenes TCHC. Por lo tanto, la presencia de postes metálicos genera artefactos resultando en la baja sensibilidad, especificidad y precisión.

Palabras clave: Tomografia computarizada de haz cónico; Radiografía dental digital; Diagnóstico.

\section{Introduction}

Vertical root fractures (VRF) may cause damage to mineralized tissues, periodontal ligaments and pulp, and has been the third most common reason for the extraction of an endodontically treated tooth (Andreasen et al, 2004). Excessive wear of dentinal walls for endodontic treatment and the use of metal posts may be associated with the cause of fractures (Khoshbin et al, 2018). Fractures are described as complete or incomplete, located in the root portion of the tooth and propagating coronarily, usually in the bucco-lingual direction (Mikrogeorgis et al, 2018). The first maxillary premolars treated endodontically are the second most affected group, representing $22.8 \%$ of all cases (PradeepKumar et al, 2016). The diagnosis is usually confirmed by clinical and radiographic characteristics, but not all the typical signs of a fractured root may be present in each case (Walton, 2017).

Radiographic images as a resource for the diagnosis of fracture are very important. However, radiographs may not confirm the presence of VRF. The fracture line is detected in only about $35.7 \%$ of cases (Wang et al, 2011). This is due to overlapping of root canals on the fracture line or other structures, the X-ray beam not parallel to the fracture plane, limited 
sensitivity, and poor image quality (Edlund; Nair; Nair, 2011; Özer, 2011). To observe the fracture, the X-ray beam must pass perpendicular to the continuity solution, so that it is necessary to take radiographs with variations in horizontal and/or vertical angles (Andreasen et al, 2004). Cone beam computed tomography (CBCT) is an important tool for the diagnosis of VRF. Threedimensional images with reconstruction, manipulation of slices and absence of overlapping structures allow a more detailed assessment. Nevertheless, the presence of artifacts may hinder and/or modify the diagnosis, particularly when hypodense images are formed (Aristizabal-Elejalde et al, 2020).

Considering the challenge of interpreting the clinical diagnosis of VRF in the most affected group of teeth and aiming at its preservation, more modern imaging techniques can motivate clinicians and endodontists to seek their answers using CBCT, assuming its superiority for diagnostic accuracy (Talwar et al, 2016). In addition, there is controversy about which imaging technique is best for diagnosing VRF in the presence of metal posts. Based on this context, the purpose of the present in vitro study was to evaluate the diagnosis of VRF in endodontically treated teeth with and without intraradicular metal posts, using the Clark technique, CBCT, as well as the interference of artifacts with the diagnosis.

\section{Methodology}

\subsection{Study design and ethical issues}

This in vitro study was approved by the Ethics Committee of the University of Pernambuco (No. 0246.0.097.000-11) following the guidelines of the Declaration of Helsinki. The study was performed in the Mechanical Testing Laboratory (Camaragibe, PE, Brazil), and the CBCT images were acquired at a private clinic of Oral and Maxillofacial Radiology (Brasília, DF, Brazil).

\subsection{Sample selection and teeth assessment}

Twenty-two uniradicular or birooted human teeth (first or second maxillary or mandibular premolars) freshly extracted for therapeutic reasons were inspected through stereoscopic glass (Callmex - Q705M, Florianópolis, SC, Brazil); $\times 10$ magnification was used to determine whether the teeth had straight roots, a formed apex and absence of cracks and/or fractures. The teeth were radiographed in the orthoradial and lateral directions to confirm the presence of a single and straight canal, the absence of calcifications, resorption, and/or anatomical variations.

The teeth were allocated to three groups: G1 (two teeth without fracture with endodontic treatment and one with an intraradicular metal post), G2 (10 fractured teeth with endodontic treatment), and G3 (10 fractured teeth with endodontic treatment plus a metal post). Endodontic preparations were performed by an endodontist using the Protaper Universal ${ }^{\circledR}$ system, $\mathrm{X}$-Smart ${ }^{\circledR}$ engine and filled with F3 main cone and Sealer 26 cement (Dentsply Sirona, York, PA, USA).

For specimen preparation, the teeth were centered in $25.0 \times 10.0 \mathrm{~mm}$ polyvinyl chloride rings and filled with chemically activated acrylic resin (JET ${ }^{\circledast}$, Artigos Odontológicos - Clássico, São Paulo, SP, Brazil). To simulate the periodontal ligament/artificial socket, a lead foil was used at the tooth/acrylic interface. Next, the lead was removed, and fluid silicone was added (Kit Express XT, 3M ${ }^{\odot}$ São Paulo, SP, Brazil).

To perform the fracture, a force perpendicular to the long axis of the teeth was exerted using a digital spacer "D" (Dentsply Sirona, York, PA, USA) with $200 \mathrm{~N}$ compression, at a speed of $0.5 \mathrm{~mm} / \mathrm{min}$ using the Kratos machine (IKCL3, Kratos Equipamentos Industriais, Cotia, SP, Brazil). The fracture was noticed by a sudden change in the graph and confirmed by inspection (Wilcox; Roskelley; Sutton, 1997). 


\subsection{Tooth exposure}

The phantom consisted of four teeth inserted into fluid silicone (Kit Express XT, 3M $\mathrm{M}^{\odot}$, São Paulo, SP, Brazil). The canine and first molar remained fixed, and premolars were assembled by simple random drawing without repetition. The Digora system was used for these procedures (Soredex, Orion Corporation, Helsinki, Finland). The fantom was positioned on an acrylic platform with a focus/phosphor plate at a distance of $30 \mathrm{~cm}$ and exposed to $60 \mathrm{kVp}, 7 \mathrm{~mA}$ and 0.3 seconds, in a dental X-ray machine (Heliodent, Sirona Dental Systems Bensheim, Germany). Clark's technique was performed in the orthoradial position and at $25^{\circ}$ on the right and left sides.

Tomographic images were captured with i-CAT New Generation ${ }^{\circledR}$ equipment (Imaging Sciences International, Hatfield, PA, USA), with $120 \mathrm{kVp}, 36.12 \mathrm{mAs}$ and a $0.5 \mathrm{~mm}$ focal point. The acquisitions involved 14 bits of resolution and $0.20 \mathrm{~mm}$ of voxel size. The scanned volume was $13 \mathrm{~cm}$ in diameter and $6 \mathrm{~cm}$ in height. Axial, sagittal, and coronal images were reconstructed. The volumetric acquisition was exported with a thickness of $0.2 \mathrm{~mm}$ in JPEG format. The images were captured by an oral radiologist.

\subsection{Image acquisition}

The images of the plaque system were coded and evaluated by three endodontists with more than 10 years of experience. After the Kappa test, three examiners were selected. The software allowed manipulation of the image, brightness, and contrast. The examiner received a questionnaire for evaluation of images selected at random, with the objective of recording the presence or absence of fracture, location of the fracture, and classification of the fracture (Aristizabal-Elejalde et al, 2020).

The CBCT images were coded and evaluated by three endodontic specialists. The examiners received guidance, images, and a questionnaire for image description. Tomographic slices were evaluated using the Microsoft Office Picture Manager image visualization program for Office 2010. The software permitted manipulation of image brightness and contrast according to the needs of the examiner. The tomographic evaluation was performed in two phases. The examiners first analyzed the selected image and then manipulated the slices along the three axes, evaluating the entire volume.

To assess the presence of artifacts, the images were saved in the XSTD (Xoran) format and exported to the Xoran/CAT program (Xoran Technologies, Ann Arbor, USA), permitting the execution of the axial, sagittal and coronal sections, and the assessment of total image volume. Super Mild Sharpen from the Xoran/CAT filter was used to adjust sharpness, brightness, contrast, and better viewing. The examiners performed analysis by answering the questionnaire about the presence and location of the fracture, the presence of artifacts and the influence of the artifact on the fracture diagnosis. The same computer was used, with a 23 "LCD" monitor model M2350D with Full HD resolution (Life's Good LG ${ }^{\circledR}$ LG Corporation, Busan, South Korea) for the interpretation of the images of the plate system and CBCT.

\subsection{Data analysis}

The Kappa index was used to select the evaluators. The Chi-Square Test of the Statistical Package for the Social Sciences (SPSS) software, version 25.0 (SPSS Inc., Armonk, NY, USA) was used. The Fisher test was applied to determine the existence of an association between sensitivity, specificity, and accuracy. All tests were applied with $95 \%$ confidence.

\section{Results}

Kappa values among the evaluators for the analysis of digital radiographic images and CBCT in the two phases of evaluation are depicted in Table 1. In the first analysis, there was no statistically significant difference between image acquisition 
systems. In the second phase, there was a statistically significant difference between evaluators 1 and $3(\mathrm{p}=0.020)$ when differentiating between teeth (first or second premolar).

Table 1. Kappa value of the examiner's first and second analyses using digital radiography and cone beam computed tomography (CBCT), as well as analysis of the first and second premolars.

\begin{tabular}{lcc}
\hline Examiners & Kappa & $p$-value \\
\hline First analysis & & \\
$\quad$ Digital radiography & & $<0.001$ \\
Examiner 1 vs. Examiner 2 & 0.619 & $<0.001$ \\
Examiner 1 vs. Examiner 3 & 0.419 & $<0.001$ \\
Examiner 2 vs. Examiner 3 & 0.475 & $<0.001$ \\
CBCT & & $<0.014$ \\
Examiner 1 vs. Examiner 2 & 0.672 & \\
Examiner 1 vs. Examiner 3 & 0.469 & \\
Examiner 2 vs. Examiner 3 & 0.661 & 0.714 \\
\hline Second analysis & & 0.264 \\
\hline First premolar & & 0.833 \\
Examiner 1 vs. Examiner 2 & 0.087 & \\
Examiner 1 vs. Examiner 3 & -0.250 & 0,667 \\
Examiner 2 vs. Examiner 3 & 0.054 & $\mathbf{0 . 0 2 0}$ \\
Second premolar & & 0.833 \\
Examiner 1 vs. Examiner 2 & 0.103 & \\
Examiner 1 vs. Examiner 3 & -0.579 & \\
Examiner 2 vs. Examiner 3 & 0.054 & \\
\hline
\end{tabular}

Source: Authors.

Table 2 shows the findings regarding the presence or absence of fractured teeth with and without a metal post determined by radiographic and CBCT evaluation, as well as variations in horizontal angulations and their respective variables. The values obtained by the examiners regarding the visualization of the fracture location did not differ significantly $(\mathrm{p}=0.863 ; \mathrm{p}=0.791$; $\mathrm{p}=0.759)$.

Table 2. Evaluation of the fracture by radiography and cone beam computed tomography (CBCT) in terms of sensitivity, specificity, and accuracy.

\begin{tabular}{lcccccc}
\hline \multirow{2}{*}{ Variables } & \multicolumn{3}{c}{ Periapical radiography } & \multicolumn{3}{c}{ CBCT } \\
\cline { 2 - 7 } & Examiner 1 & Examiner 2 & Examiner 3 & Examiner 1 & Examiner 2 & Examiner 3 \\
\hline Sensitivity & 0.574 & 0.556 & 0.510 & 0.571 & 0.526 & 0.563 \\
Specificity & 0.651 & 0.667 & 0.590 & 0.500 & 0.455 & 0.500 \\
Accuracy & 0.611 & 0.600 & 0.544 & 0.533 & 0.500 & 0.533 \\
\hline
\end{tabular}

Source: Authors.

The data shown in Table 3 regarding the presence of a fracture and its correlation with the presence of a metal post and angulation demonstrate that there was no statistically significant association ( $>>0.05)$. 
Table 3. Diagnosis of vertical root fracture by radiography and cone beam computed tomography (CBCT)

\begin{tabular}{|c|c|c|c|c|c|c|}
\hline \multirow[b]{2}{*}{ Variables } & \multicolumn{2}{|c|}{ Vertical root fracture } & \multirow[b]{2}{*}{ Sensitivity } & \multirow[b]{2}{*}{ Specificity } & \multirow[b]{2}{*}{ Accuracy } & \multirow[b]{2}{*}{$p$-value } \\
\hline & Right $n(\%)$ & Wrong $n(\%)$ & & & & \\
\hline \multicolumn{7}{|l|}{ First analysis } \\
\hline \multicolumn{7}{|l|}{ First premolar } \\
\hline $\mathrm{Rx}$ & $67(49.6)$ & $68(50.4)$ & 0.24 & 0.74 & 0.49 & $0.863^{*}$ \\
\hline CBCT & $23(51.1)$ & $22(48.9)$ & & & & \\
\hline \multicolumn{7}{|c|}{ Second premolar } \\
\hline $\mathrm{Rx}$ & $51(37.8)$ & $84(62.2)$ & 0.24 & 0.74 & 0.43 & $0.791^{*}$ \\
\hline $\mathrm{CBCT}$ & $18(40.0)$ & $27(60.0)$ & & & & \\
\hline \multicolumn{7}{|l|}{$\begin{array}{l}\text { First and second } \\
\text { premolars }\end{array}$} \\
\hline $\mathrm{Rx}$ & $118(43.7)$ & $152(56.3)$ & 0.24 & 0.74 & 0.46 & $0.759^{*}$ \\
\hline $\mathrm{CBCT}$ & $41(45.6)$ & $49(54.4)$ & & & & \\
\hline \multicolumn{7}{|l|}{ Second analysis } \\
\hline \multicolumn{7}{|l|}{ First premolar } \\
\hline \multicolumn{7}{|l|}{ Fracture } \\
\hline Yes & $8(66.7)$ & $4(33.3)$ & 0.80 & 0.20 & 0.60 & $1.000 * *$ \\
\hline No & $2(66.7)$ & $1(33.7)$ & & & & \\
\hline \multicolumn{7}{|l|}{ Second premolar } \\
\hline \multicolumn{7}{|l|}{ Fracture } \\
\hline Yes & $8(66.7)$ & $4(33.3)$ & 0.80 & 0.20 & 0.60 & $1.000 * *$ \\
\hline No & $2(66.7)$ & $1(33.7)$ & & & & \\
\hline \multicolumn{7}{|l|}{ Metal post } \\
\hline & Yes & No & & & & \\
\hline First premolar & $n(\%)$ & $n(\%)$ & & & & \\
\hline \multicolumn{7}{|l|}{ Fracture } \\
\hline Right & $5(50.0)$ & $5(50.0)$ & 0.71 & 0.38 & 0.53 & $1.000^{* *}$ \\
\hline Wrong & $2(40.0)$ & $3(60,0)$ & & & & \\
\hline \multicolumn{7}{|c|}{ Second premolar } \\
\hline \multicolumn{7}{|l|}{ Fracture } \\
\hline Right & $5(55.6)$ & $4(44.4)$ & 0.56 & 0.33 & 0.47 & $1.000^{* *}$ \\
\hline Wrong & $4(66.7)$ & $2(33.3)$ & & & & \\
\hline
\end{tabular}

*Chi-square test; **Fisher's Exact test; Source: Authors.

\section{Discussion}

The clinical signs of root fractures are nonspecific or common in endodontic and periodontal injuries. The diagnosis of VRF is a challenge for clinicians and endodontists and its early detection directly influences treatment planning (Tsesis et al, 2010). In the present study, there were no significant differences in sensitivity, specificity, or accuracy between the diagnostic methods based on the plate system and on CBCT scans, as also observed by others (Aristizabal-Elejalde et al, 2020). While the diagnostic methods were considered variable, both methods showed $50 \%$ sensitivity regarding the fracture. These findings agree with previous studies that reported specificity and accuracy values of $60 \%$ and $50 \%$ for radiography and CBCT scans (Chavda et al, 2014; Abdinian; Razavian; Jenabi, 2016). Nonetheless, a meta-analysis has detected the superiority of CBCT as an auxiliary tool for the diagnosis of VRF (Talwar et al, 2016).

Worldwide, periapical radiography is still the most widely used auxiliary method for the diagnosis of root fractures. However, when there is no separation of the fragments, loss of substantivity or signs of periodontal involvement, the fracture line is often not visualized. Despite this, radiographic examination with variation of the horizontal angle should be encouraged as the first approach to the assessment of the presence of VRF. The images obtained with periapical radiographs, when associated 
with the Clark technique, as done in the present study, increase the fracture detection index (Andreasen et al, 2004; Chavda $e t$ $a l$, 2014). On the other hand, CBCT allows three-dimensional reconstructions, eliminating overlaps and providing a more accurate analysis. The number of images is directly related to the amount of information needed to reconstruct the scanned object (Edlund; Nair; Nair, 2011). Accordingly, we observed a higher sensitivity value of $80 \%$ for volumetric analysis. However, former studies comparing the number of slices and their influence on the diagnostic capacity of VRF have observed that the number of images in different protocols did not influence the diagnosis (Bechara et al, 2013; Wanderley et al, 2017).

In the current study, two tomographic assessments were performed. In the first, only unmanipulated images were evaluated and in the second the examiners had access to the entire volume for interpretation and diagnosis of the teeth, which permitted the analysis of the sagittal, coronal, and axial views (Costa et al, 2012). To investigate the ability to diagnose root fractures by CBCT, some studies (Costa et al, 2012; Kamburoğlu et al, 2010) have used oral radiologists as examiners of the scanned images, a fact that explains the high kappa values for agreement between examiners. With the idea of obtaining data closer to clinical reality, we selected endodontists with experience in CBCT. For the analysis of unmanipulated images, the kappa values were moderate to substantial. For volumetric analysis, however, the kappa values disagreed, leading to the decision to select the examiner whose closest match was the correct diagnostic result. Notably, even using radiologist evaluators, some studies have attributed the compromised agreement between examiners to the difficulty in identifying the VRF depending on the tomograph used, the orientation of the fracture line, and the presence of intracanal materials (Costa $e t a l$, 2012; Kamburoğlu $e t$ $a l, 2010)$.

Although systematic reviews have reported that the sensitivity and specificity of CBCT are about $75 \%$ to $84 \%$ and $64 \%$ to 65\%, respectively (Chang et al, 2016; Talwar et al, 2016), a more recent study detected 24\% sensitivity when analysing unmanipulated radiographic images and $80 \%$ sensitivity for volumetric analysis, demonstrating a good ability to identify VRF (Aristizabal-Elejalde et al, 2020). Of note, we used a voxel of $0.2 \mathrm{~mm}$, as recommended by other studies (Hassan et al, 2009; Kobayashi-Velasco et al, 2017; Wenzel et al, 2009). Wenzel et al. (2009) and Özer (2011), when comparing voxel tomographs with 0.12 and $0.25 \mathrm{~mm}$ and 0.1 and $0.19 \mathrm{~mm}$, respectively, did not detect statistical differences. Likewise, Wanderley et al. (2017), when using CBCT with $0.1 \mathrm{~mm}$ voxel and different scan times in endodontically treated teeth, obtained accuracy values of $90 \%$ to $93 \%$, without statistical differences. In this respect, these studies reinforce the principles of ALARA, which advocates the use of protocols with lower doses of radiation.

The presence of biomaterials in the scanned area, such as intracanal materials, may influence the accuracy of the CBCT in the diagnosis of root fractures, compromising the quality of the image, reducing contrast, making it difficult or impossible to identify anatomical structures and making diagnosis difficult (Bechara et al, 2013). A former study evaluated the interference of four endodontic sealers with the diagnosis of VRF by means of CBCT. Sealer 26, due to its high radiopacity, revealed significantly more artifact formation (Brito-Júnior et al, 2014). In the present survey, the presence of gutta-percha, endodontic sealer, and a metal post interfered with the accuracy of the diagnostic method. In the analysis of unmanipulated images, the specificity was $74 \%$, whereas low specificity values were observed in volumetric analysis, i.e., $20 \%$, as also demonstrated elsewhere (Menezes et al, 2016). In this context, this evaluation allows a better visualization of structures, including beam hardening artifacts in general, which produce hyperdense lines in the image by optical illusion. Hypodense lines cause streaks that generate contrast, which can be confused with fracture lines, as observed in a similar manner by Edlund et al. (2011) and Wang et al. (2011). Interestingly, in our study, the examiner tended to give false-positive responses due to this occurrence, detecting fractures even when they were not present.

Herein, all teeth in the sample were treated endodontically. Considering the influence of the metal posts on the diagnosis of VRF, there was a reduction in accuracy, sensitivity, and specificity in the volumetric analysis. Nevertheless, Menezes et al. (2016) when comparing the diagnosis of VRF by CBCT in teeth without endodontic material with gutta-percha and metal posts, 
obtained high accuracy, sensitivity, and specificity values. On the basis of the above considerations, we emphasize that clinicians and endodontists should be aware of the importance of exhausting digital radiographic techniques prior to requesting CBCT as a means of diagnosing VRF since radiographic images are easier to access and represent a simple diagnostic tool. On the other hand, when CBCT is necessary, its limitations should be considered regardless of the examiner's experience (Aristizabal-Elejalde et al, 2020). Based on the study design, the results should be interpreted with caution, since the number of examiners was limited for the analyses.

\section{Conclusion}

In summary, digital radiographs and CBCT provide similar findings in the diagnosis of VRF. High sensitivity was observed in CBCT image reconstructions. However, the presence of metal posts generated artefacts, resulting in low sensitivity, specificity, and accuracy of the imaging procedures used.

\section{Acknowledgments}

The authors thank the Coordination for the Improvement of Higher Education Personnel (CAPES, Finance Code 001) for financial support. JAAA is the recipient of scholarships. Mrs. E. Greene provided English editing of the manuscript.

\section{References}

Abdinian, M., Razavian, H., \& Jenabi, N. (2016). In Vitro Comparison of Cone Beam Computed Tomography with Digital Periapical Radiography for Detection of Vertical Root Fracture in Posterior Teeth. Journal of Dentistry (Shiraz, Iran), 17(2), 84-90.

Andreasen, J. O., Andreasen, F. M., Mejàre, I., \& Cvek, M. (2004). Healing of 400 intra-alveolar root fractures. 1. Effect of pre-injury and injury factors such as sex, age, stage of root development, fracture type, location of fracture and severity of dislocation. Dental Traumatology, 20(4), $192-202$.

Aristizabal-Elejalde, D., Arriola-Guillén, L. E., Aliaga-Del Castillo, A., Ruíz-Mora, G. A., \& Rodríguez-Cárdenas, Y. A. (2020). Assessment of fractures in endodontically treated teeth restored with and without root canal posts using high-resolution cone beam computed tomography. Journal of Clinical and Experimental Dentistry, 12(6), e547-e554.

Bechara, B., Alex McMahan, C., Moore, W. S., Noujeim, M., Teixeira, F. B., \& Geha, H. (2013). Cone beam CT scans with and without artefact reduction in root fracture detection of endodontically treated teeth. Dento Maxillo Facial Radiology, 42(5), 20120245.

Brito-Júnior, M., Santos, L. A., Faria-e-Silva, A. L., Pereira, R. D., \& Sousa-Neto, M. D. (2014). Ex vivo evaluation of artifacts mimicking fracture lines on cone-beam computed tomography produced by different root canal sealers. International Endodontic Journal, 47(1), 26-31.

Chang, E., Lam, E., Shah, P., \& Azarpazhooh, A. (2016). Cone-beam Computed Tomography for Detecting Vertical Root Fractures in Endodontically Treated Teeth: A Systematic Review. Journal of Endodontics, 42(2), 177-185.

Chavda, R., Mannocci, F., Andiappan, M., \& Patel, S. (2014). Comparing the in vivo diagnostic accuracy of digital periapical radiography with cone-beam computed tomography for the detection of vertical root fracture. Journal of Endodontics, 40(10), 1524-1529.

Costa, F. F., Gaia, B. F., Umetsubo, O. S., Pinheiro, L. R., Tortamano, I. P., \& Cavalcanti, M. G. (2012). Use of large-volume cone-beam computed tomography in identification and localization of horizontal root fracture in the presence and absence of intracanal metallic post. Journal of Endodontics, 38(6), 856-859.

Edlund, M., Nair, M. K., \& Nair, U. P. (2011). Detection of vertical root fractures by using cone-beam computed tomography: a clinical study. Journal of Endodontics, 37(6), 768-772.

Hassan, B., Metska, M. E., Ozok, A. R., van der Stelt, P., \& Wesselink, P. R. (2010). Comparison of five cone beam computed tomography systems for the detection of vertical root fractures. Journal of Endodontics, 36(1), 126-129.

Hassan, B., Metska, M. E., Ozok, A. R., van der Stelt, P., \& Wesselink, P. R. (2009). Detection of vertical root fractures in endodontically treated teeth by a cone beam computed tomography scan. Journal of Endodontics, 35(5), 719-722.

Kamburoğlu, K., Murat, S., Yüksel, S. P., Cebeci, A. R., \& Horasan, S. (2010). Detection of vertical root fracture using cone-beam computerized tomography: an in vitro assessment. Oral Surgery, Oral Medicine, Oral Pathology, Oral Radiology, and Endodontics, 109(2), e74-e81.

Khoshbin, E., Donyavi, Z., Abbasi Atibeh, E., Roshanaei, G., \& Amani, F. (2018). The Effect of Canal Preparation with Four Different Rotary Systems on Formation of Dentinal Cracks: An In Vitro Evaluation. Iranian Endodontic Journal, 13(2), 163-168.

Kobayashi-Velasco, S., Salineiro, F., Gialain, I. O., \& Cavalcanti, M. (2017). Diagnosis of alveolar and root fractures in macerated canine maxillae: a comparison between two different CBCT protocols. Dento Maxillo Facial Radiology, 46(6), 20170037. 
Menezes, R. F., Araújo, N. C., Santa Rosa, J. M., Carneiro, V. S., Santos Neto, A. P., Costa, V., Moreno, L. M., Miranda, J. M., de Albuquerque, D. S., Albuquerque, M., Dos Santos, R. A., \& Gerbi, M. E. (2016). Detection of vertical root fractures in endodontically treated teeth in the absence and in the presence of metal post by cone-beam computed tomography. BMC Oral Health, 16, 48.

Mikrogeorgis, G., Eirinaki, E., Kapralos, V., Koutroulis, A., Lyroudia, K., \& Pitas, I. (2018). Diagnosis of vertical root fractures in endodontically treated teeth utilising Digital Subtraction Radiography: A case series report. Australian Endodontic Journal, 44(3), $286-291$.

Özer S. Y. (2011). Detection of vertical root fractures by using cone beam computed tomography with variable voxel sizes in an in vitro model. Journal of Endodontics, 37(1), 75-79.

PradeepKumar, A. R., Shemesh, H., Jothilatha, S., Vijayabharathi, R., Jayalakshmi, S., \& Kishen, A. (2016). Diagnosis of Vertical Root Fractures in Restored Endodontically Treated Teeth: A Time-dependent Retrospective Cohort Study. Journal of Endodontics, 42(8), 1175-1180.

Talwar, S., Utneja, S., Nawal, R. R., Kaushik, A., Srivastava, D., \& Oberoy, S. S. (2016). Role of Cone-beam Computed Tomography in Diagnosis of Vertical Root Fractures: A Systematic Review and Meta-analysis. Journal of Endodontics, 42(1), 12-24.

Tsesis, I., Rosen, E., Tamse, A., Taschieri, S., \& Kfir, A. (2010). Diagnosis of vertical root fractures in endodontically treated teeth based on clinical and radiographic indices: a systematic review. Journal of Endodontics, 36(9), 1455-1458.

Walton R. E. (2017). Vertical root fracture: Factors related to identification. Journal of the American Dental Association (1939), 148(2), 100-105.

Wanderley, V. A., Neves, F. S., Nascimento, M., Monteiro, G., Lobo, N. S., Oliveira, M. L., Nascimento Neto, J., \& Araujo, L. F. (2017). Detection of Incomplete Root Fractures in Endodontically Treated Teeth Using Different High-resolution Cone-beam Computed Tomographic Imaging Protocols. Journal of Endodontics, 43(10), 1720-1724.

Wang, P., Yan, X. B., Lui, D. G., Zhang, W. L., Zhang, Y., \& Ma, X. C. (2011). Detection of dental root fractures by using cone-beam computed tomography. Dento Maxillo Facial Radiology, 40(5), 290-298.

Wenzel, A., Haiter-Neto, F., Frydenberg, M., \& Kirkevang, L. L. (2009). Variable-resolution cone-beam computerized tomography with enhancement filtration compared with intraoral photostimulable phosphor radiography in detection of transverse root fractures in an in vitro model. Oral Surgery, Oral Medicine, Oral Pathology, Oral Radiology, and Endodontics, 108(6), 939-945.

Wilcox, L. R., Roskelley, C., \& Sutton, T. (1997). The relationship of root canal enlargement to finger-spreader induced vertical root fracture. Journal of Endodontics, 23(8), 533-534. 